\title{
Louis Adamič, Novi svet - Ijudje in vizije: Izbrani odlomki iz dvanajstih Adamičevih knjig
}

Mestna knjižnica, Grosuplje, 2015, 343 str.

V Domoznanski zbirki občin Grosuplje, Ivančna Gorica, Dobrepolje je leta 2015 izšla zanimiva knjiga izbranih besedil Louisa Adamiča, svetovno znanega ameriškega pisatelja, slovenskega izseljenca, ki se je rodil na Blatu blizu Grosupljega. Knjiga poleg odlomkov iz znanih Adamičevih knjig prinaša tudi več doslej neprevedenih besedil, študijo urednika Jakoba Müllerja in obsežno izbrano bibliografijo Louisa Adamiča, ki jo je prispeval Drago Samec. Knjiga, ki je izjemno lepo tehnično urejena, na odličnem papirju, z všečnima tiskom in likovno opremo, je izraz pozornosti intelektualcev občin izdajateljic do kulturne dediščine in zavezanosti ohranjanju poznavanja pomembnih ustvarjalcev iz domačega okolja, je pa tudi mnogo več.

Najprej je treba omeniti spremno besedo Jakoba Müllerja, izrazno svežo, pomensko pretehtano in tudi inovativno. Sam pravi, da je želel napisati tri poglavja: o pisateljevem ustvarjalnem življenju, njegovem videnju ameriškega naroda in njegovem refleksivnem preverjanju velikih sodobnih družbenih vizij. Načrt je bil ambiciozen, žal ne v celoti uresničen. Urednik je uspešno izpisal prvi del, pokazal pisateljevo življenjsko pot in v precejšnji meri argumentirano opozoril na morda zmotno prepričanje, da je bil Louis Adamič žrtev atentata, morda celo jugoslovanskih oblasti. V sedanjem času, ko se zgodovina piše na novo, ko se razkriva doslej zamolčano, je Müllerjev prispevek dragocen, saj analizira tudi možne osebne razloge pisateljeve tragične smrti. Izbor številnih in tudi prvič prevedenih odlomkov pa v veliki meri bralcu vendarle odstira tudi etnično in družbeno tematiko Adamičevih del, ki sta v spremni besedi predstavljeni bolj površno.

V objavljenih prevodih je opazna velika skrb, da bi bil jezik kar se da sodoben, čeprav gre tudi za besedila izpred druge svetovne vojne in tik po njej. Tudi že prej prevedena besedila so namreč posodobljena, izpiljena, približana današnjemu jezikovnemu občutju in danes uveljavljenemu besedju. Zato knjiga v celoti deluje enotno in sveže.

Seveda se bralcu postavlja vprašanje, kaj nam Adamič pripoveduje za današnji čas. Zakaj je treba brati besedila, ki govorijo o gospodarski krizi in kapitalizmu v tridesetih letih, revolucijah, vlogi sindikatov in oblikah njihovega boja, izseljenstvu, Ameriki kot topilnem loncu narodov, človekovi samoti. Vse našteto in še kaj, o čemer piše Adamič, so seveda teme tudi današnjega sveta. Adamičeva literatura je povsem aktualna z vidika vprašanj, ki si jih zastavljamo danes. To niso večne teme, kot je na primer Cankarjeva Skodelica kave. Adamič piše o zelo konkretnem času in prostoru, o aktualnih dogodkih in pojavih, ampak stališča, ki jih zastopa, izhode, ki jih vidi, vizije, o katerih razmišlja, nam lahko v marsičem pomagajo tudi pri našem opredeljevanju do današnje družbene stvarnosti. Prav zaradi tega pisanje o Adamiču presega priložnostne zapise ob praznovanju avtorjevih osebnih obletnic.

Povezovanje držav v Evropsko zvezo in položaj narodov ter njihovega jezika in kulture je tema državljana današnje Evrope. Vprašanje dominacije angleškega jezika 
kot jezika komunikacije med evropskimi narodi, ki posega celo na univerze, je Adamič premišljeval v ameriškem kontekstu, ob tem pa prepoznaval nacionalne korenine Američanov in položaj različnih skupin priseljencev.

Današnje sindikalno gibanje, ki je v Sloveniji po družbeni preobrazbi po osamosvojitvi doživljalo padce in vzpone, se marsikdaj omejuje zgolj na mezdno gibanje, ob branju Adamičevih besedil pa dobimo zanimive vzporednice. V času ogroženosti od terorizma se je zanimivo ponovno spomniti vzgibov za bombaške akcije nekaterih ameriških radikalnih sindikalistov še v času med obema vojnama.

Tema, ki Adamiča opredeljuje kot levičarja, je vprašanje revolucije, njegov odnos do sovjetske revolucije in diktature proletariata ter z njo povezane jugoslovanske revolucije. V ameriški družbi je nasilno, boljševistično revolucijo odklanjal kot nepotrebno. Zaradi vzvišenega cilja ni izbirala sredstev, črna usoda človeka posameznika je bila nepomembna, kvečjemu stranska škoda na poti do uresničenja svetlih idealov. Adamič je verjel v možnost sprememb kapitalizma, in to na način, ki bo ohranjal človekove pravice in njegovo dostojanstvo, bi rekli v današnjem jeziku. $V$ jugoslovanski družbi pa je revolucijo zagovarjal, podpiral in načelno tudi občudoval. Iz te opredeljenosti izvirata tudi njegova medvojna naklonjenost narodnoosvobodilnemu boju s Titom na čelu in prispevek k ameriški pomoči partizanom kot delu zavezniške antifašistične koalicije. Izbrana besedila pa vendarle kažejo, da je bil do nastajanja kulta osebnosti Josipa Broza kritičen in da ni hvalil vsega, kar je po vojni v Jugoslaviji videl. Jugoslovanski voditelji so se ob njegovih ocenah in opažanjih počutili, evfemistično rečeno, nelagodno. Zanimivi so tudi Adamičevi zapisi o nekaterih jugoslovanskih politikih (Dedijerju, Djilasu), ki kažejo, da so cenili avtorjev prispevek k širšemu mednarodnemu razumevanju dogajanja v Jugoslaviji, hkrati pa zavračali njegove kritične pomisleke in vrednotenje boljševiške revolucije.

Tenkočutno prepoznavanje človekove osamljenosti in praznote, ki sta posledici prevelikih družbenih razlik, neverjetno spominja na današnje razmere v evropski civilizaciji. Adamičev opis ljudi, ki se izgubljajo v trušču praznot, ki so izgubili vero, ki so ostali brez velike ideje in brez iluzij, bi lahko bil opis tudi današnjega človeka.

Zanimiva in zelo pronicljiva je urednikova analiza Adamičeve pisateljske tehnike. Pisatelj sam priznava, da je njegov namen pisati zanimivo in hkrati resnično ne nujno v posameznostih, ampak resnično v bistvu. Müller opisuje, kako je pisatelj aranžiral politične in osebne dogodke iz časa pred odhodom v Ameriko, da bi bila informacija kvalitetno obogatena, in kritično ugotavlja, da je pisatelj kdaj prestopil mejo te metode: ni kondenziral zgodovinske resničnosti niti ni postavljal banalne resničnosti na višjo, univerzalno raven, ampak je zašel v dezinformacijo, propagando in izkrivljanje zgodovine.

Knjiga Novi svet - ljudje in vizije je dragocen prispevek k poznavanju pisatelja in vredna branja ne samo kot dokument nekdanjih časov, ampak tudi kot izhodišče za premislek o vprašanjih naših dni. 